\title{
Theodosius Dobzhansky and the development of Genetics in Brazil
}

\author{
Crodowaldo Pavan ${ }^{1}$ and Antonio Brito da Cunha ${ }^{2}$ \\ ${ }^{1}$ Professor Emeritus da Universidade de São Paulo e da Universidade Estadual de Campinas, \\ Campinas, SP, Brazil. \\ ${ }^{2}$ Professor Emeritus do Instituto de Biociências da Universidade de São Paulo, São Paulo, SP, Brazil.
}

Theodosius Dobzhansky was a great traveler and, during his adult life, he developed this tendency thoroughly. Greater even than his roving was his obsession to convey his ideas and theories to young and old people, not only to his North-American colleagues and students, but also to many other people in different parts of the world, wherever he could go. A great part, if not all, of his trips inside and outside the USA were connected with his research, with teaching or with helping people to organize their laboratories or research projects.

He traveled to many places on the five continents, and everywhere he was he left seeds of his knowledge and thoughts. His contribution to the development of Genetics in Brazil was undoubtedly his most successful enterprise outside the USA. To understand the role Dobzhansky played in the development of Drosophila research or, better yet, of Genetics in Brazil, it is interesting to mention some circumstances involved.

In Brazil, studies and research in basic sciences started on a professional level after 1934, when the Universidade de São Paulo was founded and, more specifically, its Faculdade de Filosofia, Ciências e Letras. There, research and teaching of basic sciences were the main goal. This University was created by bringing together a number of already existing professional schools (Medicine, Engineering, Agriculture, Law, and others), some of which had conquered an international reputation, and the above mentioned new School of Philosophy, Sciences and Letters.

The State Government made enough money available to hire dozens of carefully selected foreign professors, mainly from Germany, Italy and France. These professors, hired for full-time jobs, started a high-standard science school in Brazil.

All this changed completely the country's intellectual scene, not only in the field of Physical and Natural Sciences, but also of Social Sciences and Humanities. São Paulo, and other Brazilian States to a smaller degree, experienced a true scientific and cultural Renaissance, which greatly affected the country's entire intellectuality for decades.
When Dobzhansky was for the first time invited to come to Brazil (1943), the country's academic environment was mature enough, at least, to eagerly receive all the contribution he was willing to give, as will be shown below.

It is important to add to these favorable conditions the fundamental role played for twenty years (1943-1963) by the Rockefeller Foundation, fostering sciences in Brazil and all Latin America. As a result of the situation Europe and Asia were going through after World War II, the Rockefeller Foundation shifted a great part of the funds for cooperation that it was previously applying on those continents to help sciences and agriculture in Latin America.

As important as the funds applied by the Rockefeller Foundation in Latin America was the role played by its representatives in following-up and giving suggestions to the young scientists about their running projects and future programs.

In the particular case of Prof. Dobzhansky's visits and of the development of Genetics in Brazil, we cannot go without mentioning the very friendly and competent help given to many of the Brazilian projects by Dr. Harry M. Miller Jr, Rockefeller Foundation representative at that time, and especially his suggestion made to Dobzhansky to come to Brazil instead of Central America, the region he had indicated in his application for a grant. This arrangement had been made previously by Dr. Miller Jr. and Prof. André Dreyfus, one of the founding members of the Universidade de São Paulo and one of the very few Brazilian scientists with a professorship at the above mentioned new School of Sciences.

Dobzhansky arrived in São Paulo, Brazil, with a grant from the Rockefeller Foundation on a Friday of March 1943, 60 years ago, and the next day he was collecting specimens of wild species of Drosophila with three students in the tropical forest of the Serra do Mar mountains (Atlantic Forest), thirty kilometers from the city of São Paulo.

In the original agreement it was stated that he would, beside collecting flies, give a few lectures for students and faculty members. This was changed into a special course on the Principles of Evolution, assiduously attended by over 100 people, comprising faculty members of other schools, 


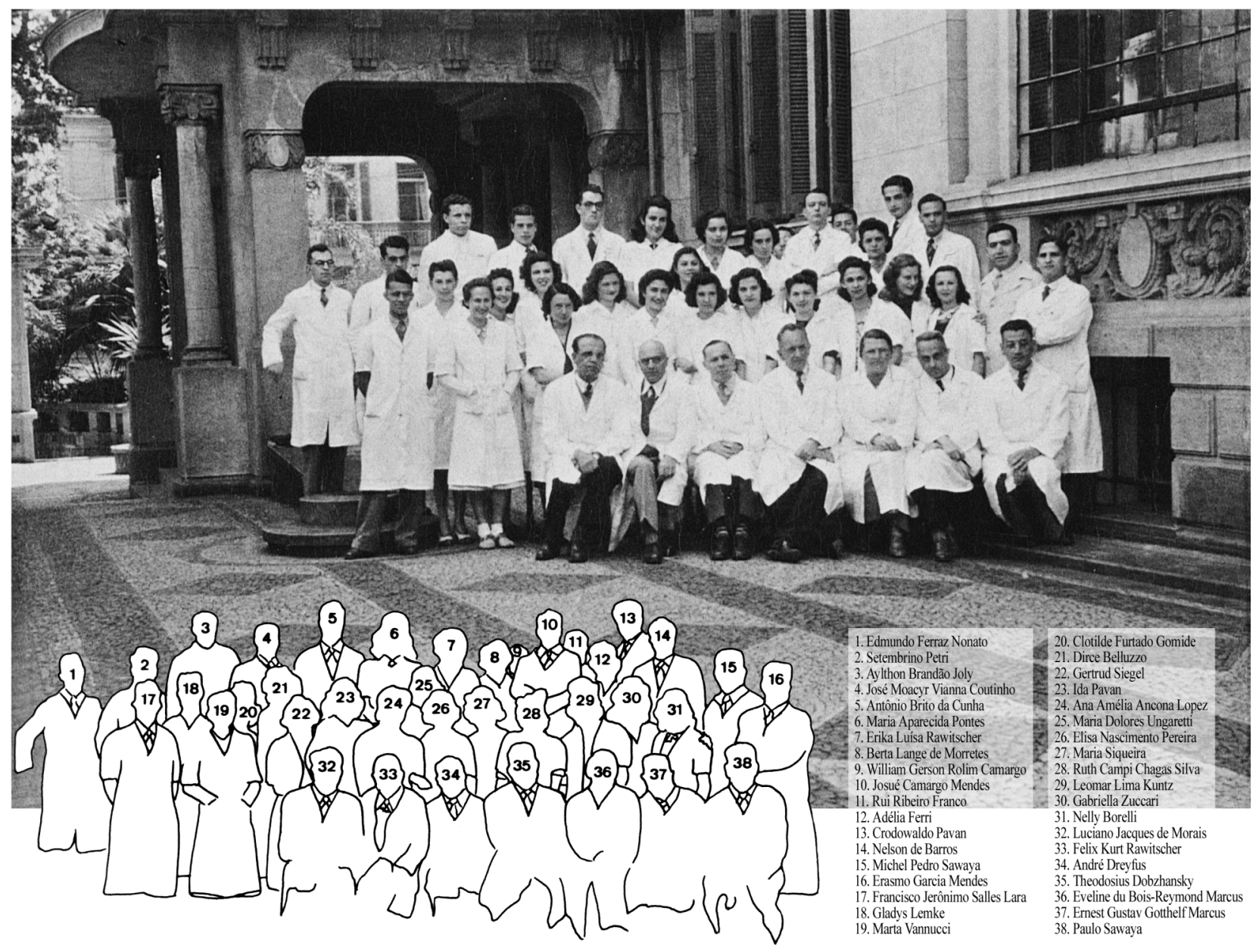

Professors and students of the Natural History course of the School of Philosophy, Sciences and Letters of the University of São Paulo during Dr. Theodosius Dobzhansky's first visit to São Paulo.

Picture taken by Paulo Sawaya at the villa located at 463, Alameda Glete, in April 1943. (Reproduction obtained from a contact copy donated by M.G.B.S. Moreira, by L. Forneris's hand, to the Memory Commission of the Department of Biology).

researchers of several institutions, students and liberal professionals, newspapermen, as well as biologists from nearby cities, like the well-known geneticists F.G. Brieger, born in Germany, and C.A. Krug, a former student of R.A. Emerson. The lectures were written by Dobzhansky in English, translated into Portuguese by Prof. Dreyfus and, after a training session for correct Portuguese pronunciation helped by the authors of this article, successfully delivered by Dobzhansky in Portuguese, with the charming Russian accent that was his trademark in any language.

After the lectures, there were frequently long discussions, where Dreyfus acted as a translator.

Regarding research in Brazil, Dobzhansky's enthusiasm was similar to the above mentioned case of a few lectures which turned into a course. He expected to find a very great biological diversity in the tropics, but reality exceeded all his expectations. He enthusiastically developed a research program on tropical species of Drosophila ${ }_{2}$ that became his main project outside the USA for the 15 years to follow, as well as of the dozens of Brazilian disciples under his leadership.

Research on species of Drosophila started at the Departmento de Biologia 60 years ago, when Dobzhansky first visited Brazil. The first phase of the work was directed towards the classification of the Drosophila species collected in the States of São Paulo and Rio de Janeiro, and in Belém (capital of the State of Pará), and towards the selection of species which were more suitable for laboratory work. The main purpose was to compare the evolutionary genetics of Neotropical and Nearctic species of Drosophila. A great deal had already been done by Dobzhansky and others, using mainly $D$. pseudoobscura and $D$. persimilis, but nothing was known about tropical species. Dobzhansky went on selecting appropriate species, taking into consideration ecological data and the facility of breeding them in the lab. In his first Brazilian paper (Dobzhansky and Pavan, 1943 a), he described 28 new species and redescribed 8 others, using modern principles. The 
species selected by Dobzhansky for future work were $D$. willistoni and $D$. prosaltans. Further papers, mainly on systematics, were published (Dobzhansky and Pavan, 1943 b; Pavan and Cunha, 1947; Burla et al., 1949; Barros, 1950; Pavan, 1950; Pavan and Nacrur, 1950; Patterson and Pavan, 1952; Burla and Pavan, 1953; Pavan and Breuer, 1954; Frydenberg, 1956; Magalhães, 1956). The descriptions also included chromosome analysis. Numerous deficiencies and a heterozygous translocation were found in $D$. ananassae (Dobzhansky and Dreyfus, 1943). A translocation between the X-chromosome and an autosome was described in $D$. prosaltans. Special papers on taxonomy and male genitalia morphology and structure were published later on (Breuer and Pavan, 1950, 1954; Magalhães and Björnberg, 1957). Dobzhansky then took the chosen species with him to New York, to produce marked strains for genetic work, planning on coming back in the period of June 1948 - August 1949, for the main work. During this period of time, research on several species proceeded in Brazil. Studies on flies of the repleta group (Dreyfus and Barros, 1948, 1949, Barros, 1949 a, b, c; Dreyfus, 1951) described chromosomal variability, aneuploidy in strains maintained in the lab, the appearance of chromosomal mutations in interspecific hybrids, and the absence of males in the hybrids between Drosophila mercatorum pararepleta and D. paranaensis. Different types of heterochromatin in $D$. nebulosa were also studied (Pavan, $1946 \mathrm{a}, \mathrm{b}$ ). Polymorphism in the pigmentation pattern of D. polymorpha was described (Cunha, 1946) and genetically studied. This polymorphism is determined by a main pair of genes, and the hybrids are heterotic, as they maintain the polymorphism (Cunha, 1949, 1951 a, 1953 a). Cytological work was done on domestic species. D. Kikkawai (then called D. montium) was found to be very variable, as it had 19 paracentric and 5 pericentric inversions, translocations, transpositions and terminal variations in the number and type of bands (Freire-Maia, 1947). This species is also polymorphous for abdomen pigmentation, which was shown to be adaptive (Freire-Maia,1949).

Drosophila willistoni and Drosophila prosaltans were irradiated by Dobzhansky and Boris Spassky in New York, inducing inversions and gene mutations. Then they prepared the strains for genetic work. The Rockefeller Foundation, that had been funding Dobzhansky's visits from the start in 1943, also provided grants for equipment and gave a fellowship to one of us (CP), enabling him to spend 18 months (Jan. 1945 - Aug. 1946) at Dobzhansky's lab in New York. Dr. Miller, an enthusiast of Brazilian genetics, helped organizing an international group to work with Dobzhansky in São Paulo in the period 1948-49 (second trip). Rockefeller fellowships were given to Hans Burla from Zurich, Martha Wedel from Buenos Aires, A.R. Cordeiro from Porto Alegre, A.G.L. Cavalcanti and C. Malogolowkin from Rio de Janeiro, to come to São Paulo to do research work and to attend Dobzhansky's courses. The research project was very broad and had two main purposes: to analyze the genetic variability of chromosomes II and III of D. willistoni and D. prosaltans, using the marked strains, and to study chromosomal variability using cytological methods. $D$. willistoni has been the most intensely studied species with regard to the concealed genetic variability. Samples from several regions of Brazil were studied (Pavan et al., 1951). In a very laborious process, a total of 2,004 chromosomes II and 1,166 chromosomes III were studied. The analysis of these chromosomes, involving the identification and counting of more than half a million flies, showed that the natural $D$. willistoni populations have a great genetic variability. Forty-two percent of the chromosomes II, and $33 \%$ of the chromosomes III cause lethal or semi-lethal effects when homozygous. Besides that, $35.9 \%$ of the chromosomes II and $27.7 \%$ of the chromosomes III, when homozygous, cause, respectively, sterility or semi-sterility of one or both sexes. Many of them determined changes in the last stage of development, and some produced visible phenotypic changes. In natural populations, virtually every chromosome of $D$. willistoni contains at least one deleterious recessive gene. Studies carried out later on, in 1955 (Pavan and Knapp, 1954), comparing the allelism rate of lethal chromosomes obtained within one population with the allelism rate of lethal chromosomes of different populations, led to the conclusion that the effective sizes of the 13 populations studied were infinite in Wright's sense, when the allelism rates were used to estimate the number of loci able to produce lethals. The number of such loci estimated in this manner for chromosome II of $D$. willistoni was 1,063 , higher than that found by Ives (1945) and Wallace (1950) for D. melanogaster. The work on chromosomal inversions of $D$. willistoni went on for several years (Cunha et al. 1950; Cunha and Dobzhansky, 1954, 1959 a). Samples were obtained from 78 localities in Florida, the Antilles, Central America, Colombia, Venezuela, Bolivia, Ecuador, Peru, Uruguay, and Brazil. The localities were selected according to their ecological characteristics, to investigate if there was a correlation between ecological conditions and chromosome structure variability. Fifty-five different inversions were found in $D$. willistoni. The geographic distribution of the inversions varied. Some were endemic, while others were found all over the immense area of distribution of the species. The degree of polymorphism of the populations varied from a mean number of 0.27 heterozygous inversions per female (St. Vincent) to a mean of 9.36 heterozygous inversions per female (Central Brazil). The degree of chromosome polymorphism is clearly related to the nature of the environment. The central part of the geographic distribution of $D$. willistoni presents the highest ecological diversification, and the populations living there tend to be more polymorphous than those living at the periphery or in isolates. Popu- 
lations which occupy rich and diversified environments are more polymorphous than those of submarginal or marginal areas. Populations which suffer competition from closely related species are less variable than those where $D$. willistoni is the dominant species. The gene combinations co-adapted and maintained by inversions represent genotypic specializations which confer higher efficiency in the exploitation of the environment. Chromosomal work done on $D$. willistoni led to the discovery of the sibling species $D$. paulistorum, $D$. equinoxialis and $D$. tropicalis (Burla et al., 1949). The structural chromosome variability of these species was also studied (Dobzhansky et al., 1950), and the degree of their chromosomal variability showed to be correlated with the width of their geographic distribution and ecological versatility. Genetic investigation was associated with intense ecological research. Relationships between Drosophila species and fruits (Pavan, 1952), local and seasonal variations in relative frequencies of species (Dobzhansky and Pavan, 1950), population density and dispersal rates of $D$. willistoni (Burla et al. 1950) were studied in different locations and seasons. The population densities of $D$. willistoni in the South were much higher than those of D. pseudoobscura in the North, and their dispersal rates much smaller. The highest population density was 1,057 specimens per $100 \mathrm{~m}^{2}$, and the smallest was 1 specimen per $100 \mathrm{~m}^{2}$.

Little was known then about the ecology of Drosophila. One of us (ABC) went to Columbia University as a fellow of the Rockefeller Foundation, when Dobzhansky returned to the USA in 1950, and started studying the influence of food, using yeasts and bacteria collected from the crop of flies in nature. Experiments were made using laboratory populations of $D$. pseudoobscura with two different gene arrangements, maintained in population cages and fed with different yeasts or bacteria. The results showed that the adaptive values of three genotypes studied varied according to the type of food available. In general, the heterozygotes were superior to the homozygotes, but the point of equilibrium changed with the type of food. In one extreme case, there was no heterosis (Cunha, 1951 b). At the same time, experiments were made at Mather, California, attracting species of Drosophila with baits fermented by different Drosophila yeasts. It was shown that different Drosophila species have different preferences, selecting their food according to the smell of the fermented baits (Cunha et al., 1951). At the same time, one of us (CP) showed that different Drosophila species also have preferences for different fruits in nature (Pavan, 1952).

In the second half of 1951, Prof. Hampton L. Carson, then at Washington University in St. Louis, came to the São Paulo laboratory to give a course and work with tropical species of Drosophila. Prof. Carson also had a grant from the Rockefeller Foundation, that granted fellowships to
Prof. Danko Brncic (Santiago de Chile) and F.M. Salzano (Porto Alegre) as well, to enable them to work with Prof. Carson and the São Paulo lab team. Prof. Carson worked with the D. bocainensis subgroup of the willistoni group (Carson, 1954). He showed that D. bocainensis and $D$. parabocainensis were morphologically indistinguishable sibling species. They occurred together in the same collected samples, but chromosome analysis proved that crossing between them did not occur in nature. They differ greatly in gene arrangements, with 13 to 26 inversions. However, they interbreed very well in the laboratory, giving fertile and healthy offspring. D. bocainoides is morphologically distinguishable and does not interbreed with the two sibling species. The species in this group seem to be highly isolated by ecological factors to which they are differentially adapted and which maintain the two sibling species apart.

During the same period of time, the chromosomal variability in populations of Drosophila species not belonging to the willistoni group was also studied (Cunha et al., 1953). D. polymorpha was found to be related to $D$. cardinoides, and $D$. guaramunu closely related to $D$. griseolineata. D. polymorpha and D. guaramunu are more common and widespread in Southern Brazil than $D$. cardinoides and D. griseolineata. Heterozygous inversions are very common in $D$. polymorpha and in D. guaramunu. Populations of D. nebulosa were also studied. Populations living in the ecologically rich and diversified environments of the cerrado and the tropical forest have more inversions than the geographically or ecologically marginal populations. Prof. Salzano's Ph.D. thesis presented at the Universidade de São Paulo had the chromosomes of $D$. guaramunu and D. griseolineata as its subject matter.

Prof. Dobzhansky returned to Brazil in 1952 (third trip), for 3 months. He worked with one of us (ABC) in the Amazonian rain forest and in the forests next to the Doce river. During this period, more data were collected on chromosomal variability as related to the environment (Cunha and Dobzhansky, 1954), and on yeast preferences (Dobzhansky and Cunha, 1955). The same yeasts were used at different locations. Populations of the same Drosophila species showed different yeast preferences in different regions.

In 1952, one of us (ABC) discovered a new $D$. neocardini subspecies. While the southern populations are composed by flies with very thin pigmentation bands on the abdomen, the flies of the Negro river (northern) region have very thick black bands. The southern populations studied are uniformly light, while that of the Negro river is uniformly dark. Two subspecies, D. neocardini mourensis and D. n. itambacuriensis, were described (Cunha, 1955 b). A paper was published in 1953 on chromosomal inversions with sex-limited effects. X-chromosomes were thought to be homogeneous, since in every generation $1 / 3$ of their re- 
cessive genes are exposed to direct selection, the males being hemizygous. Heterotic inversions were found in the $\mathrm{X}$-chromosomes of $D$. willistoni and of D. paulistorum. Large variability may be maintained in the X-chromosome by its heterotic effects in females. This finding suggests a mechanism for the maintenance of variability in parthenogenetic species in which one sex is haploid. Variability may be maintained by heterosis in the diploid sex (Cunha, 1953 b, 1956 b). The relationships between species of Drosophila and yeasts were intensely studied in the period from 1951-1956, in cooperation with Prof. A. El-Tabey Shehata from the University of Alexandria, during his one-year visit to the São Paulo lab. He came with grants from the Rockefeller Foundation and from the $C N P q$ (Brazilian National Research Council). Shehata was a specialist in yeast taxonomy. Most of the work was carried out at the São Paulo lab and in the Serra da Cantareira, a tropical forest at the outskirts of town. Yeasts were isolated from the crop of flies collected in nature. From 281 flies, 43 species of yeasts were isolated (Cunha at al., 1957). The preferences of Drosophila species regarding the yeasts were studied and shown to be very distinctive. Each species selects its diet by the smell of fermentation, and many species can coexist because, among other environmental factors, they prefer different diets. Studies were also conducted on $D$. willistoni populations with many different chromosomal inversions, maintained in population cages and fed with different yeasts. Chromosomal heterosis was found for various inversions, including some in the X-chromosome. However, the differences between $D$. willistoni populations fed with different yeasts (Cunha, 1956 a, 1957) were not as great as the one obtained in similar experiments with $D$. pseudoobscura. As a byproduct of this work and of the finding of heterosis in the X-chromosome, a hypothesis was published, in collaboration with W.E. Kerr, attempting to explain sex determination by arrhenotokous parthenogenesis (Cunha and Kerr, 1956).

Drawn by the interest in chromosomal polymorphism, chromosomal variation and adaptation, the journals "Advances in Genetics" and "Annual Review of Entomology" invited one of us (ABC) to write reviews on these themes (Cunha, 1955 a, 1960).

Prof. Dobzhansky came once more to São Paulo for the period from June 1955 to June 1956 (fourth trip), on which occasion the Rockefeller Foundation also sponsored the travel expenses and fellowships of L.C. Birch from the University of Sydney, B. Battaglia from Venice, and Ove Frydenberg from Copenhagen. Prof. Cora Pereira came from Bahia. Several important papers were published during that period (Pavan et al., 1957; Birch and Battaglia, 1957 a, b). One of them (Pavan et al., 1957) reports on the finding of Drosophila tropicalis, D. paulistorum and D. willistoni populations with very high frequencies of heterozygotes for some inversions. Heterozygote frequencies above $50 \%$ and even above $60 \%$ were found. These populations should be expected to lose part of the homozygotes produced in each generation, due to the maintenance of heterotic inversions. Despite this fact, the populations of the reported species were very large and healthy. In $D$. willistoni, there was an incipient race occupying a vast territory in which $60 \%$ of the individuals were heterozygous for a third chromosomal inversion. It was stated that part of the mutational load in the Drosophila populations and possibly in other organisms consisted of heterotic genes or gene complexes. Papers were published (Birch and Battaglia, $1957 \mathrm{a}, \mathrm{b})$ presenting interesting data on selection in D. willistoni and its abundance in relation to food. The corresponding experiments were carried out in the São Paulo lab, using several different fruits to raise the flies.

It took a lot of traveling to complete the survey on chromosomal variability in $D$. willistoni in different ecological conditions. The data obtained were also published (Cunha et al., 1959 a).

The group working on the comparison of the elimination of natural and induced lethals in nature concluded that there was no difference between them, and the first results were published (Cunha et al. 1959 b, 1960).

A series of papers was published on lethals in $D$. willistoni (Cunha et al., 1959 b, 1966; Magalhães et al.,1965 a, b; Toledo et al. 1966). The third one reached the conclusion that the same chromosome could present itself as if lethality was due to a single gene or to a synthetic lethal. Unilocus and synthetic lethality are defined with regard to the rest of the gene constellation, and are not absolute characters. A method was presented to analyze chromosomes, taking into consideration the localization of the lethality factors and their interrelations (Magalhães et al., 1965). Results obtained with spontaneous lethals and with lethals obtained by irradiation in artificial populations, maintained in population cages, were reported. The populations were started with four different lethals, two wild and two induced, each one with an initial frequency of 0.25 . After 348 days, the lethals still had frequencies between 0.03 and 0.18 . The analysis of the lethals showed that they were all capable of surviving in homozygosis in some genotypes, due to the presence of suppressor genes. The survival of the flies which were homozygous for a lethal gene was due to the presence of recessive suppressors. The proportion of lethals accompanied by their own suppressors was measured in a sample, when the population in the cage was 866 days old; it varied from 0 to 0.58 .

Another paper (Cunha et al., 1966) reports on results obtained with 5 experimental populations with known lethal gene compositions, in which a new lethal appears at a high frequency, as result of chromosomal recombination. The same thing had been shown in D. pseudoobscura. The above mentioned populations had four lethals on chromosome II, with initial frequencies of 0.25 . The elimination of 
these lethals and the appearance of new ones were studied simultaneously. The appearance rate of new lethals, as expected according to the known mutation rate, is 0.05 after five generations. However, after only three generations, the frequencies of new lethals in four populations were 0.154 , $0.100,0.212$, and 0.314 , and in the fifth population it was 0.131 after two generations. The reason for this high appearance rate of new lethals was their emergency by recombination, as it had already been obtained by Dobzhansky in D. pseudobscura. The differences in the appearance rates of new lethal chromosomes in the five populations are another indication of their origin from recombination. They would be similar, if produced by mutation. There are differences between the frequencies of lethals in chromosomes derived from males and from females, obtained in a same sample collected in nature, as described by de Toledo et al. (1966). The reason is that the collected males are immediately crossed with laboratory test flies, while the females are likewise crossed only after one generation in the lab. This deviation allowed studying the relative viability of each of the three classes normal/normal, normal/lethal, and heterozygotes for two non-alele lethals; the results of this analysis were presented. A paper sent to the Tokyo Genetics Congress (Cunha, 1968) summarized all the work on lethals and concluded that: "A single gene is an abstraction in population genetics. The results show that the very same lethals had a different behavior according to their frequencies, the rest of the genotype, the genetic constitution of the population, and the environmental conditions. To be 'classical' or to be 'balanced' is not an intrinsic property of a gene, but a circumstantial aspect of its life". A synthesis was made of what was known about mutations and their importance to man (Cunha and Pavan, 1967; Pavan and Cunha, 1967). Studies of salivary gland chromosomes in some strains of $D$. willistoni collected in nature showed strange aspects (Cunha et al., 1967), such as light, non-stained bands, broken arms, and segments with many fused bands. Those anomalies were found in cells with unidentified inclusions. They were described, and a hypothesis was made that they had been induced by infective agents. This was the reason why the paper received the title "Chromosomal diseases". These descriptions seem interesting now that chromosomal effects of foreign agents are known. It was already well known that heterozygous inversions prevented crossing-over between the inverted segments, and that there was no crossing-over in males. These facts were discovered in Nearctic species of Drosophila, and generalized for all Drosophila species. However, some unexpected results were found in $D$. willistoni, leading the researchers to question this generalization (França et al., 1968; França and Cunha, 1968). It was discovered that, in D. willistoni, recombination occurred at high frequencies between heterozygous inversions, and also that there was crossing-over in males, although with a low frequency, around 0.4 percent.

Mean frequencies of five to nine heterozygous inversions are common in females of $D$. willistoni populations. Recombination would be very rare or absent if, as in the Nearctic species studied, it did not occur between heterozygous inversions. The high frequency of heterozygous inversions in $D$. willistoni probably developed together with a genetic change in the control of crossing-over, assuring recombination between heterozygous inversions. An interesting phenomenon occurred in the populations maintained in population cages for the study of elimination of lethals (Souza et al. 1966, 1968, 1970). Normally, the larvae pupate on top of the food contained in the glass cups. However, in four cages of the same origin it was observed that many larvae left the food cups, crawled along the wooden bottom of the cages, and died from dehydration or starvation. At first, only a few larvae which left the food close to pupation time pupated normally and yielded adults. The situation changed gradually, with the appearance of larvae which left the food one day before pupation and pupated normally, giving smaller adults. The number of these larvae with early pupation and preference for the wooden bottom increased very fast. Strains of larvae pupating on the cage bottom were called "outside", and those pupating on top of the food, "inside". Inside and outside strains were very rapidly selected, by using small cages with a single cup of food. The genetic difference between them is very simple, due to a single pair of genes or perhaps to genes organized within an inversion. Outside is dominant over inside. The outside flies have a larval period of 8 days, and the inside of 9 days. The period going from the laying of the eggs to eclosion is of 11 days in the outside, and of 12 days in the inside flies. The outside flies are smaller than the inside flies, have a smaller number of bristles, and are much more active. Monomorphic and polymorphic populations were started with the same number of flies (1500): only outside, or only inside, or one half outside, or with hybrid flies. After 70 days, the adult flies were counted. The polymorphic population had about 7,000 flies, while the monomorphic population had around 4,000. Biomass was also studied, using small cages, and again the polymorphic populations largely surpassed the monomorphic ones. Those experiments were a good example of evolution in the laboratory, leading to a fast and better adaptation of the flies to a new environment, namely the population cages. We examined the food cup with only inside flies. They pupated in several layers, and the flies of the lower layers were either not able to leave the puparium or, if they left it, they were unable to cross the many layers of other pupae. In the polymorphic cages, the outside flies were free to pupate, using the whole surface of the bottom. On the other hand, in the polymorphic populations, the inside pupae suffered less competition. In our opinion, this is a clear example of evolution 
occurring before our eyes, leading to adaptation to a new ecological condition. The mating behavior was also studied, with interesting results (Souza et al.; 1966). Five males of one strain and ten females of each strain were put together for one hour in cylindrical vials of $3 \mathrm{~cm} \times 8 \mathrm{~cm}$. Twenty such experiments were made using inside males, and 20 using outside males. In the experiments with inside males, approximately the same number of outside (96) and inside (104) females were inseminated. Using outside males, 125 outside and only 3 inside females were inseminated. We do not know whether this result was due to sexual preference or to the much higher degree of activity of the outside strains.

Those were the main research works done with Dobzhansky or inspired by him. Later on, there was an adaptive radiation and many researchers changed their fields of work to other species of insects, to microorganisms and even to Human Genetics. In 1950, one of us (CP) discovered the sciarid fly Rhynchosciara angelae and its exceptionally favorable chromosomes for cytogenetic studies, and started to work with this new material. His research shifted entirely to sciarids in 1963. The same occurred with the other author (ABC) after 1967. However, we all keep in mind what we learned from Prof. Dobzhansky and remember his example of dedication to the study of biological problems with gratitude for all we owe him.

\section{References}

Barros R de (1949a) Aberrações cromosômicas em Drosophila mercatorum pararepleta. I. Aneuplóides expontâneos. Rev Bras Biol 9(3):365-376.

Barros R de (1949b) Aberrações cromosômicas em Drosophila mercatorum pararepleta. II. Uma longa duplicação expontânea adjacente e invertida. Rev Bras Biol 9(4):463466.

Barros R de (1949c) Um caso de alteração na proporção entre os sexos, em Drosophila mercatorum pararepleta. Cienc Cult 1(3):107-110.

Barros R de (1950) A new species of the genus Drosophila, with discussion about speciation in the mercatorum sub-group. Rev Bras Biol 10(3):265-278.

Birch LC and Battaglia B (1957a) The abundance of Drosophila willistoni in relation to food in natural populations. Ecology 38(1):165-166.

Birch LC and Battaglia B (1957b) Selection in Drosophila willistoni in relation to food. Evolution Int J Org Evolution 11:94-105.

Breuer ME and Pavan C (1950) Genitália masculina de Drosophila (Diptera) do grupo annulimana. Rev Bras Biol 10(4):469-488.

Breuer ME and Pavan C (1954) Genitália masculina de Drosophila (Diptera) do grupo dreyfusi. Rev Bras Biol 14(4):465-475.

Burla H and Pavan C (1953) The calloptera group of species. Rev Bras Biol 13(4):291-314.
Burla H, Cunha AB da, Cordeiro AR, Dobzhansky Th, Malogolowkin C and Pavan C (1949) The willistoni group of sibling species of Drosophila. Evolution Int J Org Evolution 3(4):300-314.

Burla H, Cunha AB da, Cavalcanti AGL, Dobzhansky Th and Pavan C (1950) Population density and dispersal rates in Brazilian Drosophila willistoni. Ecology 31(3):393-404.

Carson HL (1954) Interfertile sibling species in the willistoni group of Drosophila. Evolution Int J Org Evolution 8:148-165.

Cunha AB da (1946) Polymorphism in natural populations of a species of Drosophila. J Hered 37(8):253-257.

Cunha AB da (1949) Genetic analysis of the polymorphism of color pattern in Drosophila polymorpha. Evolution Int J Org Evolution 3(3):239-251.

Cunha AB da (1951a) Contribuição ao estudo do polimorfismo. Bol Fac Filos Cienc Letras Univ São Paulo 131(Biol Geral 9):1-58.

Cunha AB da (1951b) Modification of the adaptive values of chromosomal types in Drosophila pseudoobscura by nutritional variables. Evolution Int J Org Evolution 5(4):395-404.

Cunha AB da (1953a) A further analysis of the polymorphism of Drosophila polymorpha. Nature 171:887.

Cunha AB da (1953b) Chromosomal inversions with sex-limited effects. Nature 172:815-816.

Cunha $\mathrm{AB}$ da (1955a) Chromosomal polymorphism in the Diptera. Adv Genet 7:93-138.

Cunha AB da (1955b) Sobre duas raças de Drosophila neocardini Streisinger (Drosophilidae, Diptera). Rev Bras Biol 15(1):117-125.

Cunha AB da (1956a) Adaptation of carriers of different chromosomal types in Drosophila willistoni to a variety of environments. Rev Bras Biol 16:263-272.

Cunha AB da (1956b) Differential viability favoring inversion heterozygotes in Drosophila willistoni. Evolution Int J Org Evolution 10(3):231-234.

Cunha AB da (1957) Contribuição ao estudo da adaptação das populações de Drosophila (Diptera) a diferentes levedos. Bol Fac Filos Cienc Letras Univ São Paulo 220(Biol Geral 10): $1-60$.

Cunha AB da (1960) Chromosomal variation and adaptation in insects. Annu Rev Entomol 5:85-110.

Cunha AB da (1968) Maintenance of the lethal and detrimental genes in natural populations. Proceedings 12th International Congress of Genetics, Tokyo, 2:162-164.

Cunha AB da and Dobzhansky Th (1954) A further study of chromosomal polymorphism in Drosophila willistoni and its relation to the environment. Evolution Int J Org Evolution 8(2):119-134.

Cunha AB da and Kerr WE (1956) A genetical hypothesis to explain sex-determination by arrhenotokous parthenogenesis. Forma et Functio 1:33-36.

Cunha AB da and Pavan C (1967) O futuro biológico do homem. An Acad Bras Cienc 39 (suppl.):7-15.

Cunha AB da, Burla H and Dobzhansky Th (1950) Adaptive chromosomal polymorphism in Drosophila willistoni. Evolution Int J Org Evolution 4(3):212-235.

Cunha AB da, Dobzhansky Th and Sokoloff A (1951) On food preferences of sympatric species of Drosophila. Evolution Int J Org Evolution 5(2):91-101. 
Cunha AB da, Brncic D and Salzano FM (1953) A comparative study of chromosomal polymorphism in certain SouthAmerican species of Drosophila. Heredity 7(2):193-202.

Cunha AB da, El-Tabey Shehata A and Oliveira W de (1957) A study of the diets and nutritional preferences of tropical species of Drosophila. Ecology 38(1):98-106.

Cunha AB da, Dobzhansky Th, Pavlovsky O and Spassky B (1959a) Genetics of natural populations XXVIII. Supplementary data on the chromosomal polymorphism in Drosophila willistoni and its relation to the environment. Evolution Int J Org Evolution 13:389-404.

Cunha AB da, Toledo JS de, Pavan C, Souza HL de, Melara HE, Gabrusewycz N, Gama MR, Camargo MLP de and Mello LC de (1959b) A comparative analysis of the effects of natural and of radiation-induced lethals in heterozygous individuals and their frequencies in natural populations of Drosophila willistoni. Progress in Nuclear Energy, Series VI, Biological Sciences 2:359-363. Also in Proceedings of the Second United Nations International Conference on the Peaceful Uses of Atomic Energy 22:330-332.

Cunha AB da, Toledo JS de, Pavan C, Souza HML de, Gabrusewycz N and Gama MR (1960) Análise comparativa dos comportamentos de gens letais naturais e de gens letais induzidos por radiação em populações naturais. Atas do II Simpósio Interamericano para Usos Pacíficos da Energia Nuclear, Buenos Aires.

Cunha AB da, Magalhães LE de, Toledo JS de, Toledo Filho SA and Souza HML de (1966) On the origin of new lethal chromosomes and its rate in laboratory populations of Drosophila willistoni. Mutat Res 3:458:460.

Cunha AB da, França ZM, Gonçalves AMA, Hitelman A and Garrido MC (1967) Chromosomal diseases in Drosophila willistoni Sturtevant. Rev Bras Biol 27:113-124.

Dobzhansky Th and Cunha AB da (1955) Differentiation of nutritional preferences in Brazilian Drosophila. Ecology 36:34-39.

Dobzhansky Th and Dreyfus A (1943) Chromosomal aberrations in Brazilian Drosophila ananassae. Proc Natl Acad Sci USA 29(10):301-305.

Dobzhansky Th and Pavan C (1943a) Studies on Brazilian species of Drosophila. Bol Fac Filos Cienc Letras Univ São Paulo 36(Biol Geral 4):7-72 + 7 plates.

Dobzhansky Th and Pavan C (1943b) Chromosome complements of some South-Brazilian species of Drosophila. Proc Natl Acad Sci USA 29(11):368-375.

Dobzhansky Th and Pavan C (1950) Local and seasonal variations in relative frequencies of species of Drosophila in Brazil. J Anim Ecol 19(1):1-14.

Dobzhansky Th, Burla H and Cunha AB da (1950) A comparative study of chromosomal polymorphism in sibling species of the willistoni group of Drosophila. Am Nat 89:229-246.

Dreyfus A (1951) Analysis of sexual isolation between Drosophila paranaensis and D. pararepleta. Proc. of the Eighth International Congress of Genetics, Suppl. Hereditas, pp 564-565.

Dreyfus A and Barros R de (1948) Mutations chromosomiques chez les hybrides de Drosophila mercatorum pararepleta $\mathrm{x}$ D. paranaensis. São Paulo Médico 1:11-18.

Dreyfus A and Barros R de (1949) Sex-ratio chez certains hybrides interspécifiques de Drosophila et son interprétation par l'analyse des chromosomes salivaires. Symposium sui fattori ecologici e genetici della speciazione negli animali. Suppl. A "La Ricerca Scientifica", pp 94-104.

França ZM and Cunha AB da (1968) Crossing-over between heterozygous inversions and its relation with polymorphism in Drosophila willistoni. Rev Bras Biol 28:495-497.

França ZM, da Cunha AB da and Garrido MC (1968) Recombination in Drosophila willistoni. Heredity 23:199-204.

Freire-Maia N (1947) Sobre os cromossomos de Drosophila montium. Bol Fac Filos Cienc Letras Univ São Paulo 86(Biol Geral 7):3-19.

Freire-Maia N (1949) Balanced polymorphism in Drosophila montium. Evolution Int J Org Evolution 3:98.

Frydenberg O (1956) Two new species of Drosophila from Peru (Drosophilidae, Diptera). Rev Bras Entomol 6:57-64.

Ives PT (1945) The genetic structure of American populations of Drosophila melanogaster. Genetics 30:167-196.

Magalhães LE de (1956) Description of four new species of the saltans group of Drosophila (Diptera). Rev Bras Biol 16(3):273-280.

Magalhães LE de and Björnberg AJS (1957) Estudo da genitália masculina de Drosophila (Diptera) do grupo saltans (Diptera). Rev Bras Biol 17(4):435-450.

Magalhães LE de, Toledo JS de and Cunha AB da (1965a) The nature of lethals in Drosophila willistoni. Genetics 53:559-608.

Magalhães LE de, Cunha AB da, Toledo JS de, Toledo Filho SA, Souza HL de, Targa HJ, Setzer V and Pavan C (1965b) On lethals and their suppressors in experimental populations of Drosophila willistoni. Mutat Res 2:45-54.

Patterson JT and Pavan C (1952) Drosophila fulvimacula flavorepleta subsp. nov. In: Patterson JT (ed) A pair of allopatric subspecies belonging to the repleta species group. Univ Tex Publ 5204:114-128.

Pavan C (1946a) Chromosomal variations in Drosophila nebulosa. Genetics 31:546-557.

Pavan C (1946b) Two types of heterochromatin in Drosophila nebulosa Proc Natl Acad Sci USA 32(5):137-145.

Pavan C (1950) Espécies brasileiras de Drosophila II. Bol Fac Filos Cienc Letras Univ São Paulo 111(Biol Geral 8):1-37.

Pavan C (1952) Relações entre populações naturais de Drosophila e o meio ambiente. Cathedra Thesis, Universidade de São Paulo, São Paulo.

Pavan C and Breuer ME (1954) Two new species of Drosophila (Diptera) of the dreyfusi group (Diptera). Rev Bras Biol 14(4):459-463.

Pavan C and Cunha AB da (1947) Espécies brasileiras de Drosophila. Bol Fac Filos Cienc Letras Univ São Paulo 86(Biol Geral 7):20-64.

Pavan C and Cunha AB da (1967) Os efeitos genéticos das radiações. An Acad Bras Cienc 39 (suppl.):115-128.

Pavan C and Knapp EP (1954) The genetic population structure of Brazilian Drosophila willistoni. Evolution Int J Org Evolution 8(4):303-313.

Pavan C and Nacrur J (1950) Duas novas espécies de Drosophila (Diptera) do grupo annulimana. Dusenia 1(5):263-274.

Pavan C, Cordeiro AR, Dobzhansky N, Dobzhansky Th, Malogolowkin C, Spassky B and Wedel M (1951) Concealed genetic variability in Brazilian populations of Drosophila willistoni. Genetics 36:13-30. 
Pavan C, Dobzhansky Th and Cunha AB da (1957) Heterosis and elimination of weak homozygotes in natural populations of three related species of Drosophila. Proc Natl Acad Sci USA 43(2):226-234.

Souza HML de, Cunha AB da and Santos EP dos (1966) Assortative mating in polymorphic laboratory populations of Drosophila willistoni. Egypt J Genet Cytol 1:225-280.

Souza HML de, Cunha AB da and Santos EP dos (1968) Adaptive polymorphism developed in laboratory populations of Drosophila willistoni. Am Nat 102:583-586.
Souza HML de, Cunha AB da and Santos EP dos (1970) Adaptive polymorphism of behavior evolved in laboratory populations of Drosophila willistoni. Am Nat 104:175-189.

Toledo JS de, Magalhães LE de and Cunha AB da (1966) An effect of change of environment on the frequencies of the lethal chromosomes in Drosophila willistoni. Am Nat 100:693-696.

Wallace B (1950) Allelism of second chromosome lethals in Drosophila melanogaster. Proc Natl Acad Sci USA 36:654-657. 